\title{
A criação literária e o devaneio em Caetés
}

Suely Corvacho ${ }^{1}$

Universidade de São Paulo

\section{RESUMO}

Este ensaio procura explorar a representação do devaneio e da criação literária em Caetés, primeiro romance de Graciliano Ramos. Da análise da mise en abyme, recurso formal percebido como básico da obra, busca-se identificar os elementos que iluminam o fazer literário. O resultado permite encontrar pontos de contato e contrapontos com a posição de Freud em "Escritores criativos e devaneios" e "Sobre os sonhos".

\section{ABSTRACT}

This essay explores the representation of daydreaming and creative writing in Caetés, first novel by Graciliano Ramos. From the analysis of mise en abyme, formal expedient recognized as basic in the masterpiece, the essay seeks elements that illuminate the work of art. The result allows to find points of contact and counterpoints to Freud's position in "Creative writers and Daydreaming" and "On dreams".

\section{PALAVRAS-CHAVE}

Graciliano Ramos, Caetés, Freud, devaneios, criação literária, mise en abyme.

\section{KEYWORDS}

Graciliano Ramos,

Caetés, Freud,

daydreaming, creative writing, mise en abyme.

\footnotetext{
${ }^{1}$ Professora aposentada do Instituto Federal de São Paulo e membro do grupo de pesquisa "Crítica Literária e Psicanálise”, da FFLCH-USP.
} 


\section{Primeiras palavras}

Em "Escritores criativos e devaneio", Freud começa seu texto com o seguinte parágrafo:

Nós, leigos, sempre sentimos uma intensa curiosidade - como o Cardeal que fez uma idêntica indagação a Ariosto - em saber de que fontes esse estranho ser, o escritor criativo, retira seu material, e como consegue impressionar-nos com o mesmo e despertar-nos emoções das quais talvez nem nos julgássemos capazes. (FREUD, 1996, v. 9, p. 135)

Ainda que o desejo de Freud não possa ser satisfeito, algumas obras, como os romances modernos elaborados em torno da construção em abismo (mise en abyme), podem iluminar aspectos do fazer literário. No início do século passado, a ruptura com as formas de representação, denominada por Rosenfeld de fenômeno de desrealização, atinge a pintura, o teatro, o romance, entre outras artes. Segundo o crítico, o romance moderno substitui a continuidade temporal pela relatividade de espaço e de tempo não só no plano temático, mas também na própria estrutura da obra. Para ele, o romance moderno nasce "no momento em que Proust, Joyce, Gide, Faulkner começam a desfazer a ordem cronológica, fundindo passado, presente e futuro.’(ROSENFELD, 1996, p. 80)

Cada um dos escritores adota um caminho diferente para expressar a radical ruptura. André Gide espelha o momento da enunciação do autor-criador ${ }^{2}$ e o do protagonista, por intermédio da renovação de um antigo recurso formal. Escreve Os moedeiros falsos, registrando suas dúvidas e decisões no Diário dos moedeiros falsos; Édouard, personagem principal, compõe um romance intitulado Os moedeiros falsos e, para isso, anota seus procedimentos em um diário. O espelhamento, um livro em cujo interior o mesmo livro está sendo escrito num desdobramento sem fim, cria a ilusão de abismo, em que estão envolvidos autor, leitor e obra. Portanto, Gide retoma o antigo recurso da "narrativa dentro da narrativa" 3 e lhe dá nova configuração: a mise en abyme, que permite, entre outros objetivos, revelar os bastidores da produção literária e, em particular, o momento da criação.

De certa maneira, as primeiras composições de Graciliano Ramos parecem aspirar ao mesmo objetivo. Assim como Gide, o autor alagoano cria protagonistas que escrevem narrativas cujo título evoca o romance final: João Valério, uma novela sobre os caetés; Paulo Honório, suas memórias em São Bernardo; Luis da Silva, as angústias com seu crime. No entanto, Graciliano introduz mudanças substanciais. Uma é a substituição da terceira pessoa pela primeira; outra é o rompimento da relação de simpatia entre autorcriador e herói ${ }^{4}$. As consequências são inúmeras, entre elas, a de fornecer ainda mais elementos sobre a enunciação e o processo criativo, como veremos.

\footnotetext{
${ }^{2}$ Conforme Voloshinov/Bakhtin, não se confunde o autor-homem, componente da vida, e o autor-criador, componente da obra, pois o primeiro é sujeito de sua vida, ora potente, ora impotente, e o segundo, sujeito de sua obra, onipotente. As mesmas ideias, ao serem expressas em instâncias diferentes - na vida e na obra -, assumirão funções específicas, pois em cada instância rege um princípio produtor próprio; o da obra é o princípio criador. (BAKHTIN, 2000, p. 31)

${ }^{3} \mathrm{O}$ recurso da narrativa dentro da narrativa é antigo. Já em Mil e uma noites pode ser encontrado quando Sherazade posterga sua morte narrando uma nova aventura, noite após noite. Em Fédon, de Platão, o diálogo entre Fédon e Equécrates acolhe a narrativa do diálogo entre Sócrates e Cebes. No século XVI, Shakespeare adota o recurso com o objetivo de revelar ao espectador os elementos da intriga que escapam a algumas personagens. Conforme Victor Hugo, todas as peças do dramaturgo, com exceção de duas (Macbeth e Romeu e Julieta), oferecem a "dupla ação que atravessa o drama e que o reflete numa dimensão menor". Victor Hugo exemplifica o que chama de "a ação arrastando sua lua": "Ao lado da tempestade no Atlântico, a tempestade no copo d'água. Desse modo, Hamlet faz abaixo de si um Hamlet; mata Polônio, pai de Laertes, e eis Laertes frente a frente com ele exatamente na mesma situação que ele próprio frente a frente com Cláudio. Há dois pais a vingar. Poderia haver dois espectros." (HUGO, 2000, p. 209)

${ }^{4} \mathrm{O}$ autor-criador estabelece uma relação axiológica com o objeto do enunciado: o herói (protagonista) e seu mundo, por um lado, e uma relação de acordo ou desacordo com o leitor, por outro. Para Voloshinov/Bakhtin, "El problema de la poética sociológica estaría resuelto si se lograra explicar cada momento de la forma como una expresión activa de la valoración en estos dos sentidos: hacia el oyente y hacia el objeto de la enunciación que es el héroe." (VOLOSHINOV, 1997, p. 125)
} 
Caetés, primeiro romance de Graciliano, publicado em 1933, está longe de se circunscrever a uma história indígena ${ }^{5}$, como sugere o título, ou a um romance de costumes, como muitos o interpretaram. Tratase de um romance moderno construído em torno de dois planos diferentes, um focalizando a tentativa do protagonista - João Valério - escrever uma novela sobre os caetés, e outro explorando seu caso amoroso com a esposa do patrão. Entre os dois, o do adultério ocupa a maior parte das páginas, nas quais se pode apreciar principalmente o pacato cotidiano dos habitantes de Palmeira dos Índios no início do século XX.

A relação entre os dois planos sempre intrigou a crítica. Antonio Candido, já nos anos quarenta, chama a atenção para a "tentativa de romance dentro do romance" (CANDIDO, 1992, p. 21). Em 1977, Fernando Alves Cristóvão, em seu livro, Graciliano Ramos: estrutura e valores de um modo de narrar, faz exaustivo levantamento das obras que privilegiam o espaço literário e um escritor às voltas com a composição de um texto; mas cabe a Wander Melo Miranda, em "Graciliano Ramos ficção autobiográfica", nos anos noventa, oferecer uma interpretação sólida para compreendê-la. Caminhando pela trilha aberta por Antonio Candido, o crítico mineiro relaciona o artifício à função irônica na primeira obra de Graciliano: “a estrutura ‘em abismo’ do livro é a maior responsável pelo efeito irônico por ele atingido.” (MIRANDA, 1992, p. 55). A ironia se constrói à medida que a impossibilidade de João Valério terminar a narrativa sobre os caetés se contrapõe “à construção do relato-caeté” (MIRANDA, 1992, p. 57).

Em 1999, Marcelo Magalhães Bulhões, em Literatura em campo minado, estudando a dimensão metalinguística na obra de Graciliano Ramos, aborda o conflito entre os dois planos, explorando aspectos da enunciação. Afirmará que, em Caetés, o leitor está diante de dois livros, um falso, escrito por João Valério, e outro verdadeiro, composto por Graciliano Ramos, um simulacro e um de fato; o encontro entre os dois é tenso e contraditório, já que o livro de fato dialogará com o simulacro e também o negará.

Entre os ensaios que privilegiam a interface entre literatura e psicanálise, a mise en abyme não foi muito explorada; a preocupação esteve voltada para tentar perscrutar o homem por detrás da obra. $\mathrm{O}$ motivo não é claro. Talvez a iniciativa de Osório Borba ${ }^{6}$, nos anos quarenta, ou a sugestão lançada, na mesma época, por Álvaro Lins ${ }^{7}$, ou, ainda, a publicação de Infância, em 1945. O certo é que vários ensaios tentaram estabelecer nexos causais entre as personagens dos romances e a vida do autor. O procedimento provocou mais polêmica do que esclareceu as obras de Graciliano. Somente em 2001, com "Édipo guardalivros: leitura de Caetés”, João Luiz Lafetá rompe essa tendência e apresenta uma interpretação que não envolve a biografia do escritor.

Lafetá não elege a construção em abismo como procedimento narrativo central, mas o retardamento, e defende que a estrutura latente de Caetés é o romance familiar. Em sua leitura, estuda profundamente as projeções dos desejos do protagonista, aspecto abordado anteriormente por Lamberto Puccinelli em Graciliano Ramos - relações entre ficção e realidade. Para dar corpo a suas interpretações, o ensaísta incorpora as formulações de Freud, em "Romance familiar dos neuróticos", e de Marthe Robert, em Roman des origines et origenes du roman.

De seu ensaio, duas informações nos interessam sobremaneira: a questão do drama edipiano e os efeitos da mise en abyme. Lafetá concorda com a interpretação de Lamberto Puccinelli, que identificara o drama edipiano latente de forma oblíqua (considerando o patrão e sua esposa claras figuras substitutivas do pai e da mãe de João Valério) e desenvolve a ideia de que o ritual antropofágico, presente na novela do protagonista,

\footnotetext{
${ }^{5}$ Mais do que os sujeitos históricos que habitaram o litoral alagoano no século XVI, os caetés permitem a evocação de uma metáfora poderosa capaz de representar aspectos do funcionamento psíquico, social, literário: a antropofagia. Isso é possível porque essa tribo fica conhecida porque devora o bispo Dom Pero Fernandes Sardinha. Conforme Dantas e outros, a tribo é severamente perseguida e castigada por determinação de Mem de Sá, em 1562. (DANTAS, SAMPAIO e CARVALHO, 1998, p. 436)

${ }^{6}$ Osório Borba reconhece nas personagens de Graciliano traços do perfil psicológico do escritor. (BORBA, 1941)

${ }^{7}$ Em 1941, em "Valores e misérias das vidas secas", Álvaro Lins afirma: "A obra de Machado de Assis esclareceu o 'mistério' Machado de Assis. Os romances do sr. Graciliano Ramos esclarecerão mais tarde o 'mistério' Graciliano Ramos", sugerindo "a interpretação da sua figura psicológica através dos seus romances.” (LINS, 1987. p. 261-2).
} 
elabora algo que não pode aparecer - por ser reprimido: o desejo de matar o pai (Adrião) e dormir com a mãe (Luísa). Trata-se de uma leitura importante à qual tentaremos corroborar, destacando, em especial, o processo de identificação entre João Valério e Adrião. Especificamente sobre a mise en abyme, Lafetá afirma que a função da novela no romance é múltipla: antecipa o drama passional do romance; tem caráter compensatório para o protagonista; introduz a duplicidade de consciência; é índice de cisão da subjetividade (índice de ironia e demonismo); projeta sentimentos reprimidos (parricídio e incesto); possibilita criar um modelo de conduta que permite a conquista de Luísa; elabora o romance familiar.

Por outro lado, os ensaios mais recentes procuram cada vez mais explorar os aspectos de modernidade na obra. É o caso de "Caetés: nossa gente é sem herói”, de Erwin T. Gimenez, lançado em 2013 como um dos posfácios da edição comemorativa de Caetés. O crítico defende que as cenas da vida cotidiana servem como motivos para as reflexões do protagonista que, pouco a pouco, desperta para uma consciência mais complexa. Trata-se pois de um esboço de romance moderno cujo eixo integrador é o deslizamento do campo social para a meditação intimista.

O presente artigo dialoga com as três linhas de pesquisa aqui brevemente expostas. Com Erwin T. Gimenez, defendemos, como já foi mostrado, a existência de traços de modernidade em Caetés; com Wander Melo Miranda e Marcelo Magalhães Bulhões, a centralidade da mise en abyme; e com João Luiz Lafetá buscaremos elementos de natureza psicanalítica para refletir sobre o devaneio e o processo de criação literária.

\section{Caetés: Devaneio e criação literária}

Em Caetés, fruto da mise en abyme, temos duas relações simultâneas, a do protagonista e seu interlocutor, e a do autor e o leitor-crítico. Uma é o avesso da outra. Para João Valério, o leitor é facilmente ludibriado, impressiona-se com miçangas literárias, fica extasiado diante de um vocabulário desconhecido e aquilata o valor da obra por aquilo que não entende ${ }^{8}$. Essa imagem não é casual, ela se constrói a partir do próprio comportamento do jovem, que tem ambições intelectuais, porém pouca disposição para os estudos. Crítico em relação à atitude frente à leitura dos companheiros, Valério amplia seu repertório sem disciplina e sem dedicação. Seu método consiste em escutar a discussão dos mais eruditos ou anotar uma palavra desconhecida para uma postergada pesquisa que jamais se realiza. No entanto, é capaz de intervir nas discussões ou reproduzir a palavra ${ }^{9}$ sem constrangimentos e, se algum pudor emerge, ele reside na hipótese de sua fraude ser descoberta e não na falta de franqueza intelectual ${ }^{10}$. Em última instância, João Valério se comporta como o leitor projetado em sua narrativa.

O autor, ao contrário, estabelece uma relação de cumplicidade e de confiança com o leitor-crítico de seu texto. Por intermédio do jogo verbal que vela e revela, reserva-lhe conhecimento privilegiado sobre a paixão do rapaz, o adultério e as armadilhas nas quais o protagonista fica preso. O jogo é simples. Confiando na curiosidade intelectual do destinatário, o autor deixa provérbios em francês inacabados,

\footnotetext{
${ }^{8}$ Em seus devaneios, o protagonista afirma: “O meu fito realmente era empregar uma palavra de grande efeito: tibicoara. Se alguém me lesse, pensaria talvez que entendo de tupi, e isso me seria agradável”. (RAMOS, 1998, p. 40)

${ }^{9}$ Lembramos aqui a passagem com a palavra irreprochável. O protagonista a ouve na festa de Vitorino: “Gravei na memória esta palavra, para procurar a significação dela no dicionário, e aproximei-me de um grupo de moças [...]” (RAMOS, 1998, p. 75). Logo depois, constrangido diante de um convite silencioso de uma das moças para dançar, declara: "o jantar tinha sido irreprochável." (RAMOS, 1998, p. 85)

${ }^{10}$ Interrogado por Padre Atanásio sobre Augusto Comte, João Valério responde: "Declarei que aquele senhor era, não obstante, um inspirado poeta, e logo me arrependi de ter falado. Sei realmente, sem nenhuma sombra de dúvida, que Augusto Comte foi grande, mas ignoro que espécie de grandeza era a dele. Depois serenei, porque ninguém ali, excetuando Nazaré, compreendia um disparate.” (RAMOS, 1998, p. 100)
} 
citações em suspenso e cenas cuja função escapa à primeira vista na economia da obra ${ }^{11}$. Mediante pesquisa, o leitor-crítico consegue completá-los e articulá-los com o enredo, revelando, assim, vários sentidos do romance. Em suma, parece projetar um interlocutor que, diante das dificuldades impostas à leitura, não se abala, toma a iniciativa de buscar soluções e assume uma postura ativa, o que resulta na decifração da linguagem de Caetés.

A construção em abismo possibilita também observar João Valério agindo, devaneando e escrevendo sua novela, o que permite acompanhar como o fato cotidiano se transforma em matéria narrativa. Para examinar o devaneio, nos apoiaremos em "Escritores criativos e devaneios", de Freud, procurando destacar pontos de contato ou contrapontos. Já na análise da criação literária, o procedimento será diferente. Como o psicanalista deixou mais hipóteses do que estudos sobre o assunto, buscaremos, na novela de João Valério, elementos que compõem a obra literária, depois, os complementaremos com a análise da produção do autor-criador. Após esse levantamento, apreciaremos os pontos de contato entre a representação de Graciliano Ramos e as observações de Freud em "Sobre os sonhos".

\section{A transfiguração no devaneio}

O romance inicia-se in media res com uma ousadia do protagonista. João Valério comparece ao sarau oferecido por Adrião Teixeira, seu patrão, permanece após a saída dos convidados e, intempestivamente, beija a jovem esposa do patrão, Luísa, que o repele com rigor:

Luísa quis mostrar-me uma passagem no livro que lia. Curvou-se. Não me contive e dei-lhe dois beijos no cachaço. Ela ergueu-se, indignada:

- O senhor é doido? Que ousadia é esta? Eu...

Não pôde continuar. Dos olhos, que deitavam faíscas, saltaram lágrimas. Desesperadamente perturbado, gaguejei tremendo:

- Perdoe, minha senhora. Foi uma doidice.

- É bom que se vá embora, gemeu Luísa com o lenço no rosto.

- Foi uma tentação, balbuciei sufocado, agarrando o chapéu. Se a senhora soubesse... Três anos nisto! O que tenho sofrido por sua causa... Não volto aqui. Adeus. (RAMOS, 1998, p.7)

Após o diálogo, o rapaz deixa a casa dos patrões e perambula pela cidade, surpreso com sua iniciativa e aterrorizado com os desdobramentos de seu arroubo. Os dias se sucedem e, para seu grande alívio, as consequências imaginadas não se concretizam. Isso o leva a devanear:

- Por que foi que ela não contou aquilo?

Veio-me um pensamento agradável. Talvez gostasse de mim. Era possível. Olhei-me ao espelho. Tenho o nariz bem feito, os olhos azuis, os dentes brancos, o cabelo louro - vantagens. Que diabo! Se ela me preferisse ao marido, não fazia mau negócio. E quando o velhote morresse, que aquele trambolho não podia durar, eu amarrava-me a ela, passava a sócio da firma e engrendrava filhos bonitos.

Embrenhei-me numa fantasia doida por aí além, de tal sorte que em poucos minutos Adrião se finou, Padre Atanásio pôs a estola sobre a minha mão e a de Luísa, os meninos cresceram, gordos, vermelhos, dois machos e duas fêmeas. À meia-noite

\footnotetext{
${ }^{11}$ Exemplo disso é uma insistente dúvida do protagonista. No capítulo 12, uma personagem secundária, que lhe dissera, em francês, uma frase a respeito da facilidade com que se juntam as pessoas que se assemelham, mostra a João Valério um quadro com a representação de Marino Faliero. O fato intriga o rapaz e, por várias vezes, ele se pergunta quem terá sido Marino Faliero. A curiosidade do guarda-livros não é grande o bastante para que o fato seja esclarecido no nível narrativo. O leitor-crítico, no entanto, recordará que o velho Faliero, esposo de uma jovem mulher, acaba morrendo em circunstâncias trágicas, porque seu nome é envolvido em uma pilhéria pública. Por sinal, a proximidade entre a história de Faliero e a de Adrião permite perceber que o quadro antecipa o drama final do patrão.
} 
andávamos pelo Rio de Janeiro; os rapazes estavam na academia tudo sabido, quase doutor; uma pequena tinha casado com um médico, a outra com um fazendeiro - e nós íamos no dia seguinte visitá-las em São Paulo. (RAMOS, 1998, p. 20-1)

Examinando o devaneio, nota-se uma "correção" do mundo segundo o desejo do protagonista, aspecto que Freud descreve da seguinte forma em "Escritores criativos e devaneio":

Vamos agora examinar algumas características do fantasiar. Podemos partir da tese de que a pessoa feliz nunca fantasia, somente a insatisfeita. As forças motivadoras das fantasias são os desejos insatisfeitos, e toda fantasia é a realização de um desejo, uma correção da realidade insatisfatória. (FREUD, 1996, v. 9, p.137)

No devaneio, Adrião morre, Valério herda a firma e a esposa. Além disso, sai de Palmeira dos Índios direto para a capital do país e seus filhos dão continuidade à ascensão social, quer por meio da formação acadêmica, quer por meio do casamento. Percebe-se que, ao lado do amor de Luísa, o desejo de ascensão social está muito presente, disputando o primeiro plano em relação ao amor. Isso confirma o que Freud diz acerca das fantasias. Para o psicanalista, os desejos motivadores dividem-se em dois grupos: desejos ambiciosos, cujo fim é elevar a personalidade do sujeito, e desejos eróticos. "Nos homens jovens os desejos egoístas e ambiciosos ocupam o primeiro plano, de forma bem clara, ao lado dos desejos eróticos." (FREUD, 1996, v. 9, p. 138)

Ainda com Freud, no texto já citado, aprendemos que a relação entre fantasia e tempo é quase sempre muito complexa:

A relação entre a fantasia e o tempo é, em geral, muito importante. É como se ela flutuasse entre três tempos - os três momentos abrangidos pela nossa ideação. $\mathrm{O}$ trabalho mental vincula-se a uma impressão atual, a alguma ocasião motivadora no presente que foi capaz de despertar um dos desejos principais do sujeito. Dali, retrocede à lembrança de uma experiência anterior (geralmente da infância) na qual esse desejo foi realizado, criando uma situação referente ao futuro que representa a realização do desejo. O que se cria então é um devaneio ou fantasia, que encerra traços de sua origem a partir da ocasião que o provocou e a partir da lembrança. Dessa forma o passado, o presente e o futuro são entrelaçados pelo fio do desejo que os une. (FREUD, 1996, v. 9, p.138)

Essas palavras encontram eco no devaneio de João Valério. O arroubo do rapaz (situação motivadora do presente) desperta a fantasia retificadora da realidade que se apoia em lembranças do passado (a experiência de proprietário) e imagina um futuro no qual realizará plenamente seu desejo ambicioso e erótico. No entanto, o sujeito insatisfeito não usa apenas um tipo de fantasia para reparar seu mundo imperfeito. É o que se constata examinando outro devaneio do narrador. Conforme suas palavras, a ideia de compor uma novela ocorre justamente quando perde a herança e a condição social:

Iniciei a coisa [composição de um livro] depois que fiquei órfão, quando a Felícia me levou o dinheiro de herança, precisei vender a casa, vender o gado, e Adrião me empregou no escritório como guarda-livros. (RAMOS, 1998, p.19)

Diante das perdas, decide escrever a história sobre os caetés com o fim de conseguir o reconhecimento futuro: 
(...) Talvez eu pudesse também, com exígua ciência e aturado esforço, chegar um dia a alinhavar os meus caetés. Não que esperasse embasbacar os povos do futuro. Oh! não! As minhas ambições são modestas. Contentava-me um triunfo caseiro e transitório, que impressionasse Luísa, Marta Varejão, os Mendonça, Evaristo Barroca. Desejava que nas barbearias, no cinema, na farmácia Neves, no café Bacurau, dissessem: "Então já leram o romance do Valério?" Ou que, na redação da Semana, em discussões entre Isidoro e Padre Atanásio, a minha autoridade fosse invocada: "Isto de selvagens e histórias velhas é com o Valério" (RAMOS, 1998, p. 47)

Novamente se percebe a mesma relação entre fantasia e tempo, ou seja, o passado, o presente e o futuro se entrelaçam pelo fio do desejo. A situação presente (perda dos pais, da herança etc.) evoca a experiência emocional satisfatória do passado e fantasia a situação futura (o reconhecimento dos pares). O reconhecimento conquistado quando se torna um dos proprietários da firma Teixeira parece revelar que a composição do livro perde sua função, logo é abandonada. Logo, tanto o devaneio no Rio de Janeiro, desfrutando dos bens recebidos com o casamento, quanto o reconhecimento como escritor obedecem ao mesmo processo e aspiram ao mesmo objetivo, isto é, retificar a realidade.

\section{A transfiguração na criação literária do protagonista}

A criação literária, por sua vez, procura também, em certa medida, corrigir o mundo, porém adota procedimentos mais complexos. Comecemos pela escolha do assunto. Nessa direção, é o próprio guardalivros quem nos dá as primeiras informações:

Também aventurar-me a fabricar um romance histórico sem conhecer história! Os meus caetés realmente não têm verossimilhança, porque deles apenas sei que existiram, andavam nus e comiam gente. $\mathrm{Li}$, na escola primária, uns carapetões interessantes no Gonçalves Dias e no Alencar, mas já esqueci quase tudo. Sorria-me, entretanto, a esperança de poder transformar esse material arcaico numa brochura de cem a duzentas páginas, cheias de lorotas em bom estilo, editada no Ramalho. (RAMOS, 1998, p. 19-20)

Entre os "carapetões" de Gonçalves Dias e os de Alencar, parece que o rapaz se inclina ao último, já que flagramos paralelismo entre a escolha do assunto por Alencar e por João Valério. O primeiro escolhe o argumento histórico da fundação de sua terra natal para compor Iracema: a lenda do Ceará, um texto dirigido aos conterrâneos. De forma análoga, João Valério, morador de Palmeira dos Índios, escolhe um argumento histórico, ocorrido nas costas alagoanas, para compor uma novela dirigida aos concidadãos. Mesmo que o rapaz afirme que suas ambições são modestas, o paralelismo revela o desejo de ter o mesmo destino de Alencar: a imortalidade.

No entanto, o material escolhido não entra na composição da obra sem profundas alterações. Conforme Freud:

Mesmo nessas obras [que não são uma criação original do autor, mas uma reformulação de material preexistente e conhecido], o escritor conserva uma certa independência que se manifesta na escolha do material e nas alterações do mesmo, às vezes muito amplas. (FREUD, 1996, v. 9, p. 141)

É o que se vê na novela de João Valério. Mesmo escolhendo um argumento histórico, o jovem conserva certa independência, introduzindo uma cena com personagens inexistentes, tecida a partir das lembranças do cotidiano, do repertório literário que possui e dos desejos que o habitam. Dados os limites deste artigo, examinaremos apenas a primeira cena da novela: 
De repente imaginei o morubixaba pregando dois beijos na filha do pajé. Mas, refletindo, compreendi que era tolice. Um selvagem, no meu caso, não teria beijado Luísa: tê-la-ia provavelmente jogado para cima do piano, com dentadas e coices, se ela se fizesse arisca. Infelizmente não sou selvagem. E ali estava, mudando a roupa com desânimo, civilizado, triste, de cuecas. (RAMOS, 1998, p. 20)

A cena imaginada remete ao episódio ocorrido na sala do patrão e, como nos sonhos infantis ${ }^{12}$, procura realizar o desejo ativado durante o dia anterior. Embora pareça que será descartada, veremos que a ideia permanece, pois, na sequência, o protagonista dá forma ao pajé a partir das características físicas de Adrião. Percebe-se, portanto, que o episódio histórico foi alterado com a introdução do triângulo amoroso transfigurado em uma relação tribal, composta pela filha do pajé (Luísa), o pajé (Adrião) e o morubixaba (João Valério), em que o interdito moral - o casamento - é também modificado.

\title{
2.1. Transfiguração de Luísa
}

A transfiguração de Luísa em filha do pajé pode ser associada a Iracema, obra de José de Alencar, conforme livre-associação do próprio narrador:

[Um personagem, falando nas barbas de Abraão]... Isto me fez pensar no José de Alencar, que também foi um cidadão excessivamente barbado.

Daí passei para Iracema, da Iracema para o meu romance, que ia naufragando com os restos do bergantim de D. Pero. (RAMOS, 1998, p. 97)

Ao transfigurar Luísa em filha do pajé, alguns desejos ausentes no devaneio se revelam. O primeiro é impedir qualquer contato erótico entre os patrões. Quando transfigura Adrião em pajé, pai de Luísa, o protagonista aproveita um dado real - a diferença de idade entre eles - e cria um impedimento de natureza incestuosa para evitar que, no plano da fantasia, Adrião se aproxime da mulher. Portanto, a interdição real, o casamento, obstáculo para a realização dos desejos do guarda-livros, é transformada em tabu (incesto).

Outro desejo que parece animar a fantasia do guarda-livros é a ideia de ser o primeiro a tocar Luísa. Afinal, se a esposa de Adrião fosse a filha do pajé, seria virgem como Iracema, seu passado sexual estaria apagado e ele, João Valério, seria o primeiro a tocá-la. Hipótese que encontra eco em um dos devaneios do rapaz:

\begin{abstract}
(...) Tencionava poder um dia, com o consentimento dela, apertar-lhe as mãos, correr os lábios por aqueles dedos brancos e finos, pelos braços, até o cotovelo. Em momentos de otimismo aventurei-me a chegar à espádua. Não era uma aspiração demasiado exigente, e eu punha tanto respeito nela que excluí a ideia de que aquilo constituísse uma traição ao Teixeira. Decidi logo que um homem tão prático não havia ainda babujado o braço de Luísa e que pelo menos esta parte do corpo dela não lhe pertencia. Convicção idiota, evidentemente. Eu me contentava com o braço - e achava excessivo. (RAMOS, 1998, p. 85-6)
\end{abstract}

\footnotetext{
${ }^{12}$ Analisando sonhos em que o conteúdo manifesto e latente coincidem, frequentes nos sonhos das crianças, Freud afirma: "O elemento comum em todos esses sonhos infantis é evidente. Todos realizaram desejos que se haviam ativado durante o dia, mas permaneceram irrealizados. Os sonhos foram simples e indisfarçadas realizações de desejo." (FREUD, 1996, v. 5, p.665)
} 
Além disso, a condensação de Luísa e Iracema permite imaginar que a expectativa do rapaz é trilhar o mesmo caminho que Martim. Como guardiã do segredo da jurema, Iracema deveria permanecer virgem, porém rompe seu voto e se entrega a Martim; de forma similar, a jovem esposa do patrão deve permanecer fiel ao compromisso matrimonial, porém Valério deseja que ela rompa o voto e se entregue a ele. Ainda, nesse paralelo, interessa explorar mais uma sutileza do enredo. Martim está sob efeito do alucinógeno ao possuir Iracema, ele imagina que sonha, quando, na verdade, mantém relações com a moça. Essa particularidade o livra da responsabilidade da transgressão. De forma análoga, João Valério tenta se livrar da responsabilidade por suas ações, atribuindo-as à tentação, como vimos na cena inicial do romance (em que rouba o beijo) e na consumação do ato: "Tinha-me vindo a tentação, uma tentação de olhos azuis e cabelos louros, e depois de escorregarmos, nada valia ralar-me por uma coisa que a cidade ignorava, que Adrião não suspeitaria.” (RAMOS, 1998, p. 141)

\subsection{A transfiguração de Adrião}

A transfiguração de Adrião resulta mais da condensação e deslocamento de figuras do cotidiano do que das literárias, ainda que se perceba alguns traços de Araquém ${ }^{13}$, pai da lendária Iracema. Conforme o narrador: "Dei pedaços de Adrião Teixeira ao pajé: o beiço caído, a perna claudicante, os olhos embaçados; para completá-lo, emprestei-lhe as orelhas de Padre Atanásio” (RAMOS, 1998, p. 40). Entre as características, chama a atenção as "orelhas de Padre Atanásio", uma vez que não cumprem nenhuma função aparente, a não ser o fator humorístico, pois são "enormes” (RAMOS, 1998, p. 181). No entanto, o vigário de Palmeira dos Índios remete à outra autoridade eclesial presente na história oficial, o bispo Sardinha, o que permite conjecturar a existência de uma associação que parte do responsável pelas questões religiosas no Brasil no século XVI, desliza para Padre Atanásio, também religioso, daí desloca para o pajé, figura religiosa da tribo e, por fim, toca em Adrião, velho como Araquém.

Apesar de todas as figuras utilizadas na transfiguração de Adrião colaborarem para possibilitar que Luísa esteja livre para o protagonista (o padre e o bispo pelo celibato que lhes é imposto; o pajé, pelo lado paternal, uma vez que a figura de Luísa já fora condensada na de Iracema), a sinuosa associação nos leva a ver um paralelo entre o fim do bispo Sardinha e o de Adrião, revelando o desejo canibalístico do protagonista. Mesmo que, com razão, Puccinelli e Lafetá tenham interpretado o ritual antropofágico como a elaboração de algo que não pode aparecer na novela (parricídio e incesto), como já mencionamos, consideramos necessário destacar a identificação do jovem com o comerciante. Acreditamos que esse componente do complexo edipiano colabora para reforçar a ideia de antropofagia mais claramente, pois, segundo Freud, identificação e canibalismo são processos que podem ser comparados:

A base do processo [transformação do relacionamento parental em superego] é o que se chama 'identificação' - isto é, a ação de assemelhar um ego a outro ego, em conseqüência do que o primeiro ego se comporta como o segundo em determinados aspectos, imita-o e, em certo sentido, assimila-o dentro de si. A identificação tem sido comparada, não inadequadamente, com a incorporação oral, canibalística, da outra pessoa. (FREUD, 1996, v. 22, p. 68)

Ao perder a condição social, o jovem torna-se empregado de Adrião, que passa a ocupar um lugar

\footnotetext{
${ }^{13}$ Alencar descreve Araquém da seguinte forma: “O ancião fumava à porta, sentado na esteira de carnaúba, meditando os sagrados ritos de Tupã. O tênue sopro da brisa carmeava, como frocos [sic] de algodão, os compridos e raros cabelos brancos. De imóvel que estava, sumia a vida nos olhos cavos e nas rugas profundas." (ALENCAR, 1990, p. 16)
} 
contraditório, porque ele é, ao mesmo tempo, protetor e rival. Como no ritual antropofágico, João Valério admira as qualidades do rival (a perspicácia) e deseja incorporar suas qualidades (ocupar seu lugar na firma e no casamento). De forma similar aos antropófagos, o rapaz almeja também incorporar o nome e o discurso do oponente. Quando se torna sócio, não altera a razão social, apropriando-se do nome comercial construído por Adrião. E a partir daí, utiliza o seguinte discurso: "um negociante não se deve meter em coisas de arte" (RAMOS, 1998, p. 214), bordão similar ao do velho comerciante, que "entendia bem de comércio; o resto era filosofia" (RAMOS, 1998, p. 8). Embora o protagonista não inclua o canibalismo em suas reflexões finais ${ }^{14}$ nem consiga concluir o capítulo em que descreve a refeição totêmica, a verdade é que, após a morte de Adrião, João Valério ressurge como um autêntico antropófago, uma vez que o processo de identificação com o seu rival fica claramente visível.

\subsection{A transfiguração de João Valério}

Parece paradoxal que o protagonista escolha o que ele considera ser um selvagem para se transfigurar, quando a história oficial lhe oferece a possibilidade de ser um dos três sobreviventes ${ }^{15}$, e a tradição literária, outras alternativas, entre elas, como já vimos, Martim. No entanto, diferente dos anteriores, o morubixaba pode praticar a antropofagia e desfrutar de privilégios típicos do pai primevo ${ }^{16}$. $\mathrm{O}$ primeiro é o de manifestar a agressividade sem freios. A figura composta pelo protagonista é violenta: "Fiz do morubixaba um bicho feroz, pintei-lhe o corpo e enfeitei-o." (RAMOS, 1998, p. 40). Violência que penetra o âmbito amoroso. Conforme Lamberto Puccinelli e João Luiz Lafetá, a novela do rapaz cria um modelo de conduta que permite conquistar Luísa, modelo cuja expressão pode ser vista no primeiro encontro: "- Um beijo! Balbuciei como um demente. Soltei-lhe as mãos, agarrei-lhe a cabeça, beijei-a na boca, devagar e com voracidade. Apertei-a, machucando-lhe os peitos, mordendo-lhe os beiços e a língua." (RAMOS, 1998, p. 138).

O segundo privilégio está relacionado ao poder, já que morubixaba é o chefe dos chefes, segundo Alencar:

Neste livro [Ubirajara], como em Iracema, preferi traduzir o termo indígena tuxaba por chefe, e fui levado pela razão de ser, além de muito apropriado e vulgar, um termo nobre e suscetível de entrar no estilo o mais elevado, sem laivos de afetação. Ao morubixaba pela mesma razão chamei chefe dos chefes. (ALENCAR, 2015, p. 138)

$\mathrm{O}$ último, está relacionado à poliginia. Embora corteje apenas uma mulher, o jovem funcionário devaneia com várias: Luísa, Marta Varejão, D. Josefa, entre outras. Seus devaneios amorosos vêm repletos

\footnotetext{
${ }^{14}$ No final do romance, o jovem escritor, percebendo a agressividade e a facilidade com que transforma um taco de bilhar em arma para matar o delator, a inconstância de seus sentimentos, a propensão a aceitar sem reversas o que lhe impingem e a admiração pelas coisas brilhantes, pelas miçangas literárias, conclui que no íntimo é um caeté. Entre os argumentos apresentados e a conclusão a que chega há um problema: os caetés, habitantes primevos de Alagoas, entram para a história não por essas qualidades, mas porque, em 1556, devoram o primeiro bispo do Brasil e sua comitiva. A omissão do costume antropofágico chama a atenção do leitor, porque não é a primeira vez que o protagonista revela dificuldade em tratar o tema.

${ }^{15}$ Segundo Frei Vicente do Salvador, a comitiva era composta por mais de cem pessoas, tendo sobrevivido apenas dois índios e um português que sabia o tupi. Em suas palavras: “(...) Antônio Cardoso de Barros, que fora provedor-mor, e dois cônegos, duas mulheres honradas, muitos homens nobres e outra muita gente, que por todos eram mais de cem pessoas, os quais, posto que escaparam do naufrágio com vida, não escaparam da mão do gentio caité [sic] que naquele tempo senhoreava aquela costa, o qual, depois de roubados e despidos, os prenderam e ataram com cordas, e poucos a poucos os foram matando e comendo, senão a dos [sic] índios que iam desta Bahia, e um português que sabia a língua." (SALVADOR, 1982, p. 148)

${ }^{16}$ Para Freud: "Naturalmente, não há lugar para os primórdios do totemismo na horda primeva de Darwin. Tudo que aí encontramos é um pai violento e ciumento que guarda todas as fêmeas para si próprio e expulsa os filhos à medida que crescem." (FREUD, 1996, v. 13, p. 145)
} 
de ambição. João Valério sonha ora com Luísa ora com Marta Varejão ${ }^{17}$, porém com a mesma estrutura: morre o provedor e ele herda o patrimônio. É ainda a ambição que pode ter afastado os amantes. Passados três meses da morte de Adrião, o guarda-livros torna-se sócio da firma e, em vez de se casar com viúva, começa a devanear com D. Josefa, filha de Vitorino Teixeira, irmão de Adrião ${ }^{18}$. Como um guerreiro, que vai sistematicamente à luta para capturar o inimigo, incorporar seu nome e suas qualidades, tornando-se então um morubixaba, João Valério decide-se por D. Josefa Teixeira, porque assim pode assumir o poder total da firma Teixeira, completando, dessa forma, o ciclo da antropofagia.

\section{A novela do protagonista e o romance do autor}

Ainda que o guarda-livros seja um escritor de poucos recursos, a análise da primeira cena de sua novela permite perceber que, assim como o devaneio, a criação literária também cumpre o papel de corrigir a realidade, realizando desejos. Alguns são similares: a ambição, o desejo de reconhecimento e o de imortalidade. Outros são mais específicos da composição literária, por exemplo, o desejo de possuir uma mulher virgem, o da antropofagia, o de ter poder absoluto sobre o grupo, entre outros. Eles dão vazão à parte reprimida do "homem subterrâneo", como nos ensina Antonio Candido, em "Os bichos do subterrâneo" (CANDIDO, 1992, p. 71).

Além disso, os elementos que dão forma aos desejos e constituem o assunto da narrativa de João Valério provêm de várias esferas: da história oficial (a morte do bispo Sardinha), da história literária (em particular de Iracema) e da história cotidiana do rapaz. A relação do narrador com as três histórias não é neutra, assume uma atitude responsiva: altera a história oficial, introduzindo uma cena (beijo do morubixaba); qualifica as obras dos antecessores literários de carapetões; e, por fim, retifica a história cotidiana segundo seu desejo (Luísa, como filha do pajé, está livre do contrato matrimonial e pode se entregar ao morubixaba, João Valério).

Esse amálgama proveniente de diferentes instâncias é constantemente modificado pela necessidade de dar impressão de verdade à matéria narrada, isto é, pela verossimilhança ${ }^{19}$. João Valério escreve para um leitor facilmente manipulável, mesmo assim ele toma inúmeros cuidados para que seu texto não caia no descrédito. Quer descrever o naufrágio do bispo Sardinha, mas, por desconhecer o local exato, vai à procura do vigário para socorrê-lo. Depois, tenta escrever a devoração do bispo Sardinha, cujo preparo nem imagina, então busca informações culinárias com a dona da pensão. Compõe uma cena na qual o morubixaba beija Luísa, porém se autocorrige, como vimos. Tudo denota preocupação com o leitor e com a verossimilhança.

\footnotetext{
${ }^{17}$ Em seu devaneio, “(...) Depois obteria umas entrevistas à noite, à janela, e, conversa puxa conversa, pregava-lhe, ao cabo de uma semana, meia dúzia de beijos. Ficávamos noivos, casávamos, D. Engrácia morria. Imaginei-me proprietário, vendendo tudo, arredondando aí uns quinhentos contos, indo viver no Rio de Janeiro com Marta, entre romances franceses, papéis de música e flores de parafina. Onde iria morar? Na Tijuca, em Santa Teresa, ou em Copacabana, um dos bairros que vi nos jornais. Eu seria um marido exemplar e Marta uma companheira deliciosa, dessas fabricadas por poetas solteiros. Atribuí-lhe os filhos destinados a Luísa, quatro diabretes fortes e espertos. Suprimi radicalmente Nicolau Varejão, ser inútil.” (RAMOS, 1998, p. 35)

${ }^{18}$ Nas palavras do protagonista: "Gosto da Teixeira. Tem uma linda perna, uns lindos olhos, várias habilidades e é alegre como um passarinho. No silêncio do meu quarto, penso às vezes que a vida com ela seria doce. E digo a mim mesmo que ainda podemos ter quatro filhos vermelhos, fortes e louros. Parece-me que vou casar com a Teixeira" (RAMOS, 1998, p. 215)

${ }^{19}$ Segundo Rosenfeld: "Ainda que a obra não se distinga pela energia expressiva da linguagem ou por qualquer valor específico, notar-se-á o esforço de particularizar, concretizar e individualizar os contextos objectuais, mediante a preparação de aspectos esquematizados e uma multiplicidade de pormenores circunstanciais, que visam a dar aparência real à situação imaginária. É paradoxalmente esta intensa 'aparência' de realidade que revela a intenção ficcional ou mimética. Graças ao vigor dos detalhes, à 'veracidade' de dados insignificantes, à coerência interna, à lógica das motivações, à causalidade dos eventos, etc., tende a constituir-se a verossimilhança do mundo imaginário.” (ROSENFELD, 1987, p. 20-1)
} 
Certamente os elementos captados não esgotam o assunto, mas iniciam um levantamento que pode ser complementado com a análise da produção do autor, lembrando que a mise en abyme, em Caetés, dá o privilégio de observar duas comunicações simultâneas. Dadas as inúmeras situações criadas pelo autor-criador, destacaremos apenas algumas, em função dos limites deste artigo.

Analisemos as intervenções elaboradas pelo autor-criador a partir do uso da ironia. Suficientemente estudada por críticos consagrados, a ironia percorre todo o livro, como afirma Antonio Candido: "é o momento da ironia [na obra de Graciliano]. Não no sentido anatoliano e macio, mas já travada de certo humor ácido que, em relação aos outros, se aproxima do sarcasmo e, em relação a si mesmo, da impiedade" (CANDIDO, 1992, p. 20). Wander Miranda, por sua vez, explora diversas situações em que a construção em abismo é responsável pelos efeitos irônicos. Em terreno tão bem cultivado, pouco pode ser acrescentado, contudo, se recorrermos ao legado teórico de Bakhtin, algo ainda pode ser plantado. Como vimos, o estudioso russo nos ensina que o exame da relação axiológica do autor criador com o objeto do enunciado é fundamental para a compreensão da obra. Nessa perspectiva, em Caetés, o autor estabelece uma posição de superioridade em relação ao herói e de cumplicidade em relação ao leitor, ao ironizar o protagonista e seu mundo. A partir dessa posição hierárquica e desse ponto de vista, ele se manifesta acerca de vários temas, dentre os quais destacamos os relacionados ao imaginário romântico.

Examinando o espaço reservado ao triângulo amoroso, é possível conjecturar que o autor esteja interessado em revelar os bastidores do amor romântico. O romance de João Valério e Luísa apresenta todos os elementos que animam esse imaginário: idealização da mulher amada, distância entre os amantes e presença de obstáculo (marido). À medida que o casal se aproxima, a paixão decresce ${ }^{20}$ e, quando finalmente Adrião morre, os jovens amantes se separam. $\mathrm{O}$ anticlímax permite ao leitor concluir que boa parte da paixão do romântico casal era fruto da distância e dos obstáculos ${ }^{21}$.

A crítica do autor não se restringe apenas ao protagonista e seu mundo, atinge também os próceres do Romantismo no Brasil. Enquanto o guarda-livros se embaraça com as lembranças das leituras infantis, o autor recorre a esse mesmo legado com familiaridade e destreza e, graças a isso, cria ironia e humor. Por exemplo, a confusão em torno dos objetos de adorno do feroz morubixaba:

Mas aqui surgiu uma dúvida: fiquei sem saber se devia amarrar-lhe na cintura o enduape ou a canitar. Vacilei alguns minutos e afinal me resolvi a pôr-lhe o enduape na cabeça e o canitar entre parênteses. (RAMOS, 1998, p. 40)

A dúvida do protagonista é estratégia do autor para dessacralizar o texto de Gonçalves Dias. Em "I-Juca-Pirama", o prisioneiro que será objeto do ritual antropofágico dos Timbiras é assim adornado: "Brilhante enduape no corpo lhe cingem,/ Sombreia-lhe a fronte gentil canitar." (DIAS, 1982, p. 18). Considerado como um dos poemas mais bem elaborados do Romantismo brasileiro, os adereços provocam outros sentimentos no texto de Graciliano. A solenidade e o peso do ritual transformam-se em humor, já que o tapa-sexo acaba na cabeça, e em ironia, porque os limites do protagonista não prejudicam apenas sua imagem, mas respingam também no texto consagrado.

O expediente é similar na aproximação de Iracema, de José de Alencar, e a novela do guarda-livros. Enquanto o escritor cearense elabora um texto em que celebra o encontro amoroso entre portugueses e índios, João Valério busca um episódio cujo final é um banquete antropofágico. O paralelismo acentua o

\footnotetext{
20 "Não lhe caí aos pés, com uma devoção mais ou menos fingida. A felicidade perfeita a que aspirei, sem poder concebêla, rapidamente se desfez no meu espírito. Livre dos atributos que lhe emprestei, Luísa me apareceu tal qual era, uma criatura sensível que, tendo necessidade de amar alguém, me preferira ao Dr. Liberato e ao Pinheiro, os indivíduos moços que frequentavam a casa dela." (RAMOS, 1998, p. 140)

${ }^{21}$ A conclusão pode ser reforçada pela descrição da estrela-testemunha, inicialmente comparada a um "Sol complacente" (RAMOS, 1998, p. 103) e, ao término, a um astro como outros: "A estrela vermelha brilhava à esquerda. Pareceu-me pequena, como as outras, uma estrela comum. Comum, como as outras.” (RAMOS, 1998, p. 217)
} 
contraste entre a versão romântica, marcada pelo signo da harmonia e do amor, e a versão mais realista, sob o signo do conflito e da morte. Ao colocar, lado a lado, um dos maiores expoentes do Romantismo brasileiro e um escritor sem qualquer criatividade, o autor apequena Alencar.

Como se vê, a análise de duas intervenções do autor-criador é suficiente para jogar luz sobre alguns liames entre a obra e o contexto social. As suas recorrentes iniciativas para abalar os pilares românticos não é uma atitude isolada, faz parte de um movimento amplo, no qual se envolveram não só Graciliano Ramos, mas toda primeira geração Modernista, como aponta Marcelo Bulhões. Ilumina também outra faceta da escolha do tema indígena. $\mathrm{O}$ caeté condensa elementos provenientes da demanda interna do protagonista e, ao mesmo tempo, da necessidade do autor criticar o Indianismo romântico, participando da polêmica de seu tempo.

Diante disso, pode-se afirmar que Graciliano Ramos, escritor criativo, oferece um objeto afinado com as mais avançadas ideias estéticas de seu tempo: um romance moderno cuja sofisticada arquitetura - mise en abyme - produz duas comunicações distintas, que permitem levantar alguns dos principais elementos que compõem uma obra literária. A dimensão mais subterrânea, configurada na novela de João Valério, revela a criação literária realizando desejos, cujas formas de expressão são provenientes de diferentes esferas (cotidiano, história oficial e tradição literária). A dimensão mais social, configurada nas intervenções do autor, mostra que a obra depende também da relação do autor com seu contexto, da interlocução com seus pares, da polêmica estética de sua época, que, por sua vez, não está dissociada das demais séries culturais.

\section{Palavras finais}

Ainda que não tenha sido possível iluminar de onde o escritor criativo retira seu material, como almejava Freud, a representação de Caetés traz algumas contribuições relacionadas à dimensão mais subterrânea da obra literária que surpreendem pela proximidade com as formulações freudianas aqui apresentadas. Já na reflexão sobre o devaneio, havíamos percebido que alguns aspectos da representação do autor de Caetés lembravam os descritos por Freud, em "Escritores criativos e devaneios", como a realização do desejo (corrigindo a realidade insatisfatória), a natureza dos desejos (ambiciosos e eróticos) e a relação da fantasia com o tempo. Na análise da criação literária, outras proximidades foram aparecendo, especialmente as relacionadas ao trabalho onírico, formuladas em "Sobre os sonhos". Uma delas é a realização de desejos despertados durante o dia, cujo exemplo mais expressivo é a cena do beijo entre o morubixaba e a filha do pajé, tentando realizar o desejo ativado ${ }^{22}$ na sala de Adrião.

Outra proximidade é a condensação. Se compararmos a cena do beijo imaginado pelo protagonista e o material conseguido após a análise não resta dúvida de que o trabalho criativo opera intensa condensação. O mecanismo é apreensível também nas personagens criadas pelo guarda-livros, como a figura feminina que condensa características de Luíza e de Iracema e sob a qual inúmeros desejos convergem. A curiosa condensação de dois traços excludentes (a mulher casada e a virgem) não é também estranha ao espaço onírico, pois Freud, analisando o sonho de uma mulher que se via carregando um ramo de flores brancas, afirma: "O trabalho do sonho gosta particularmente de reproduzir duas representações contrárias [inocência e seu oposto] por uma mesma formação mista” (FREUD, 1996d, p. 672)

O deslocamento é outro ponto a tocar os dois saberes. Ainda que afirme que, dos caetés, saiba apenas que existiam, andavam nus e comiam gente, João Valério não consegue descrever o ritual canibalesco

\footnotetext{
22 Freud afirma acerca dos instigadores do sonho: "Quando pedimos ajuda à análise, descobrimos que todo sonho, sem nenhuma exceção possível, remonta a uma impressão dos últimos dias (...)” (FREUD, 1996, v. 5, p. 674).
} 
em sua novela, tampouco incluí-lo em suas reflexões finais. A recorrente omissão e os sucessivos deslocamentos para afastar Adrião do bispo Sardinha, e João Valério da antropofagia, evocam um dos mais notáveis ensinamentos freudianos sobre o funcionamento dos sonhos. Para Freud, as pessoas se enganam ao considerar o elemento mais nítido no sonho o mais importante: "mas, na verdade [graças ao deslocamento ocorrido], muitas vezes um elemento indistinto é o que se revela como o derivado mais direto do pensamento onírico essencial" (FREUD, 1996, v. 5, p. 673).

É bem verdade que as aproximações entre a representação de Graciliano e as palavras de Freud pedem aprofundamento, uma vez que não se pode confundir, por exemplo, o deslocamento do trabalho onírico, que procura ocultar o sentido do sonho, tornando "irreconhecível a ligação entre o conteúdo onírico e os pensamentos oníricos" (FREUD, 1996, v.5, p. 673), e o deslocamento na criação literária, que não perde de vista os liames de construção (coerência e coesão). Contudo, as analogias aqui esboçadas parecem indicar que, assim como os sonhos constituem uma das vias, entre outras, de acesso ao inconsciente, a mise en abyme parece ser uma das portas de entrada para investigar os mecanismos envolvidos no fazer literário.

Sem minimizar a imensa distância entre ficção e realidade, entre Literatura e Psicanálise, acreditamos que, cada um, em seu próprio caminho, o crítico, interessado em perceber como o escritor criativo constrói o texto, e o psicanalista, preocupado em conhecer o sofrimento humano para, com sua escuta e pontuação, quebrar as certezas do discurso do analisando, poderão, como bons observadores, encontrar frestas pelas quais identificarão alguns pontos de confluência entre os dois saberes e, quiçá, confirmarão a hipótese de Freud:

Assim, a arte constitui um meio-caminho entre uma realidade que frustra os desejos e o mundo de desejos realizados da imaginação - uma região em que, por assim dizer, os esforços de onipotência do homem primitivo ainda se acham em pleno vigor. (FREUD, 1996, v. 13, p. 189) 